\title{
Factors and conditions for the development of the digital economy in Russia
}

\author{
Elvira Karieva ${ }^{1}$, Liliya Akhmetshina ${ }^{2, *}$, and Olga Fokina $^{3}$ \\ ${ }^{1}$ Russian presidential Academy of national economy and public administration Perm branch, 614060, \\ Perm, Gagarin, 10, Russia \\ ${ }^{2}$ Financial University under the Government of the Russian Federation, 125993, Moscow, \\ Leningradsky, 49, Russia \\ ${ }^{3}$ Vyatka State University, Moskovskaya str., 36, Kirov, 610000, Russia
}

\begin{abstract}
The use of digital technologies in order to increase the efficiency of production processes, distribution and consumption of the results of economic activities, and their participation in the creation of fundamental innovative developments that allow reaching a high level of application of knowledge in the field of science and technological progress, is one of the modern economic models. The purpose of the study is to assess the factors that ensure the formation of the digital economy in Russia and develop proposals aimed at accelerating the introduction of digital technologies into the economy and social sphere. Among the factors determining the formation of the digital economy in Russia, it is necessary to highlight the following: the level of digital competency skills, the effectiveness of R\&D and innovation activities, the level of development of information and communication infrastructure. As a result of the study, conclusions were drawn about the presence of the necessary prerequisites for accelerating the pace of digitalization of the Russian economy. An obstacle on this path is the lack of coordinated actions on the part of the state, business and the scientific community, the low readiness of the regulatory framework for high rates of technology development and the spread of digital solutions. In order to test the effectiveness of new developments, it seems reasonable to use digital "regulatory sandboxes".
\end{abstract}

\section{Introduction}

The transformation of the Russian economy into a new state called the "digital economy" is an objective inevitability and necessity for further development and competitiveness in world markets, since the spread of digital technologies currently determines the trajectories of economic and social development, and the formation of a digital economy is a priority for most economically developed countries. At the same time, only an integrated approach, involving the solution of a wide range of tasks - from building a basic information and communication infrastructure to developing a state policy for the

\footnotetext{
* Corresponding author: akhmetshinalg@mail.ru
} 
development of the digital economy and programs to support the introduction of digital technologies, will ensure the formation of the digital economy [1].

In Russia, the accelerated introduction of digital technologies in the economy and social sphere as one of the national development goals is determined by the Decree of the President of the Russian Federation dated May 7, 2018 No. 204 "On national goals and strategic objectives of the development of the Russian Federation for the period up to 2024". As part of the implementation of this Decree, on the basis of the "Digital Economy of the Russian Federation" program approved by the Order of the Government of the Russian Federation dated July 28, 2017 No. 1632-r, a national program "Digital Economy of the Russian Federation" was formed in 2019, which includes six federal projects: "Normative regulation of the digital environment", "Personnel for the digital economy", "Information infrastructure", "Information security", "Digital technologies", "Digital public administration" $[2,7]$.

Successful implementation of this goal is possible in the presence of a number of significant factors that determine the formation of the digital economy and the creation of favorable conditions for technological development. At the same time, despite the already "traditional" nature of this area for the country's economy, a full-fledged legal framework and regulatory mechanisms have not yet been formed. The circumstances noted above determined the relevance of the study.

\section{Materials and Methods}

The study was carried out on the basis of statistical data on the development of the digital economy, research materials by foreign and domestic authors. As research methods, the study of various sources of information with the subsequent generalization of data, analytical and comparative methods were used.

The development of digitalization in the Russian economy involves the use of information and communication technologies (ICT) in its various sectors (households, industrial companies, services), which contributes to the formation of conditions for the acquisition of specific competencies by the population and enterprises and allows maximizing the benefits from the spread of ICT. One of the essential factors in the development of the digital economy is the level of digital competency skills.

It should be noted that in terms of the level of education and preparation of the population for digitalization, there is a positive trend towards an increase in the share of the employed population with a higher education, from $31.2 \%$ in 2012 to $35.2 \%$ in 2019 . But at the same time, the number of students getting higher education is decreasing by $65.3 \%$ over the period 2012-2019. If in 2012 there were 424 such students for 10,000 people, then in 2019, this indicator was 277 people (fig. 1). The share of students getting higher education in the total population has decreased from $4.2 \%$ in 2012 to $2.8 \%$ in 2019 [10]. 


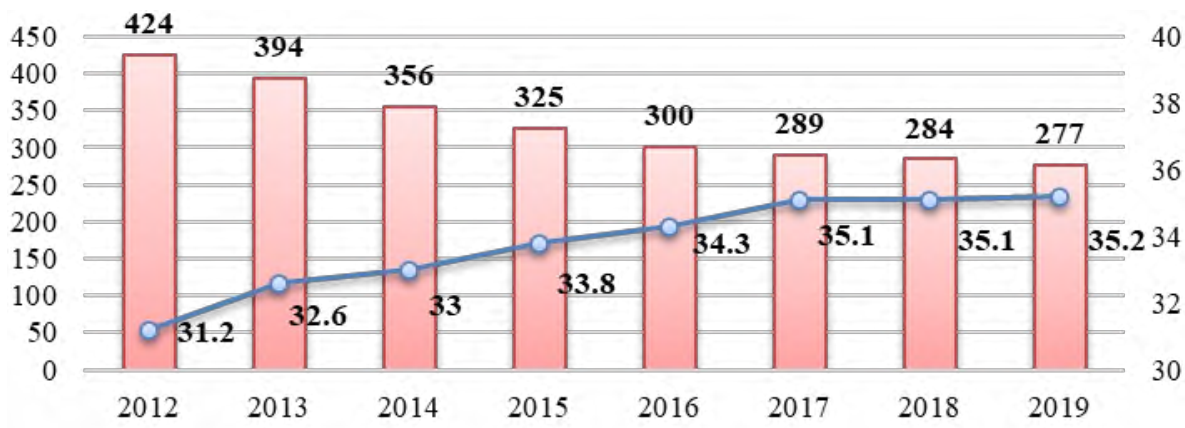

$\square$ Number of students in educational programs of higher education per 10,000 people, $\mathrm{ppl}$

$-0-$ Share of the employed population with higher education, $\%$

Fig. 1. Dynamics of the share of the employed population with higher education and the number of students in educational programs of higher education per 10,000 people, 2012-2019 [10].

Nevertheless, the number of students admitted to state educational institutions of higher education in the area of training "Informatics and Computer Engineering" per 10,000 people increased from 9 people in 2012 up to 15 people in 2019. A similar situation is observed in the number of graduates of state educational institutions of higher education in the area of training "Informatics and Computer Engineering". The number of graduates increased 4 times, from 2 people in 2012 up to 9 people in 2019 (Fig. 2). Consequently, the field of digital transformation will be provided with the required number of specialists constantly and cumulatively.

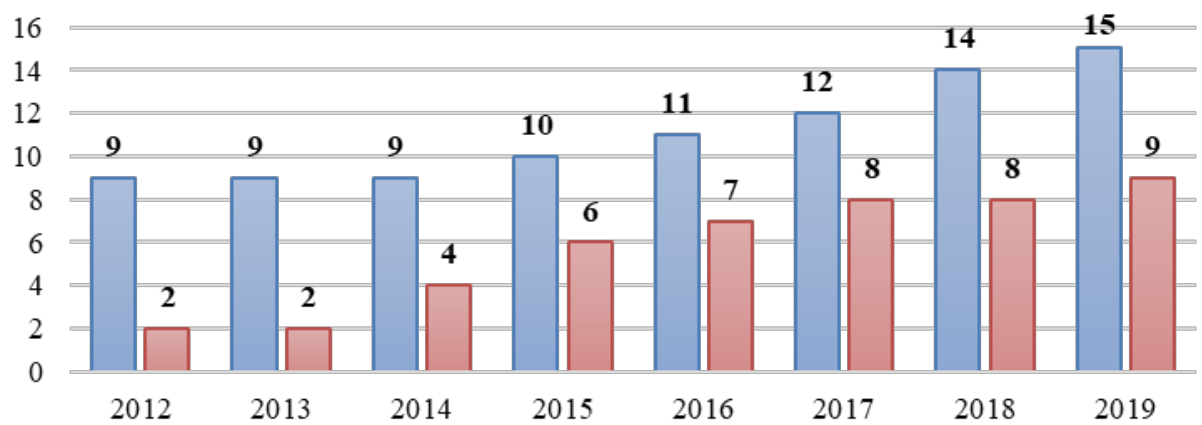

$\square$ Number of students admitted to state educational institutions of higher education in the area of training "Informatics and Computer Engineering" per 10,000 people

$\square$ Number of graduates of state educational institutions of higher education in the area of training "Informatics and Computer Engineering" per 10,000 people

Fig. 2. Dynamics of the number of future specialists in the field of digital technologies, 2012-2019, people [10].

Innovation capital plays an important role in the development of digital technologies. The resource base in the form of research and development in the field of ICT has a very contradictory trend for the analyzed period 2012-2019. Thus, internal expenditures on research and development in current prices amounted to $1,134.7$ billion rubles in 2019, 
having increased from 699.9 billion rubles in 2012 by $62 \%$. The number of researchers who performed research and development per 10,000 people employed in the economy fell from 54.8 people in 2012 up to 49 people in 2019 , i.e. by $11 \%$. The share of domestic spending on research and development in total GDP remained unchanged at $1.03 \%$, while the share of domestic spending on research and development in the ICT sector in total domestic spending on research and development decreased from $2.9 \%$ to $2.4 \%$ [10].

The institutional and infrastructural environment is a significant factor in the formation of the digital economy. Nowadays, its condition does not meet the requirements of an innovative economy $[13,14]$. According to the data in Fig. 3, there are no grounds for technological breakthroughs in production and increasing the susceptibility of business to scientific and technological innovations.

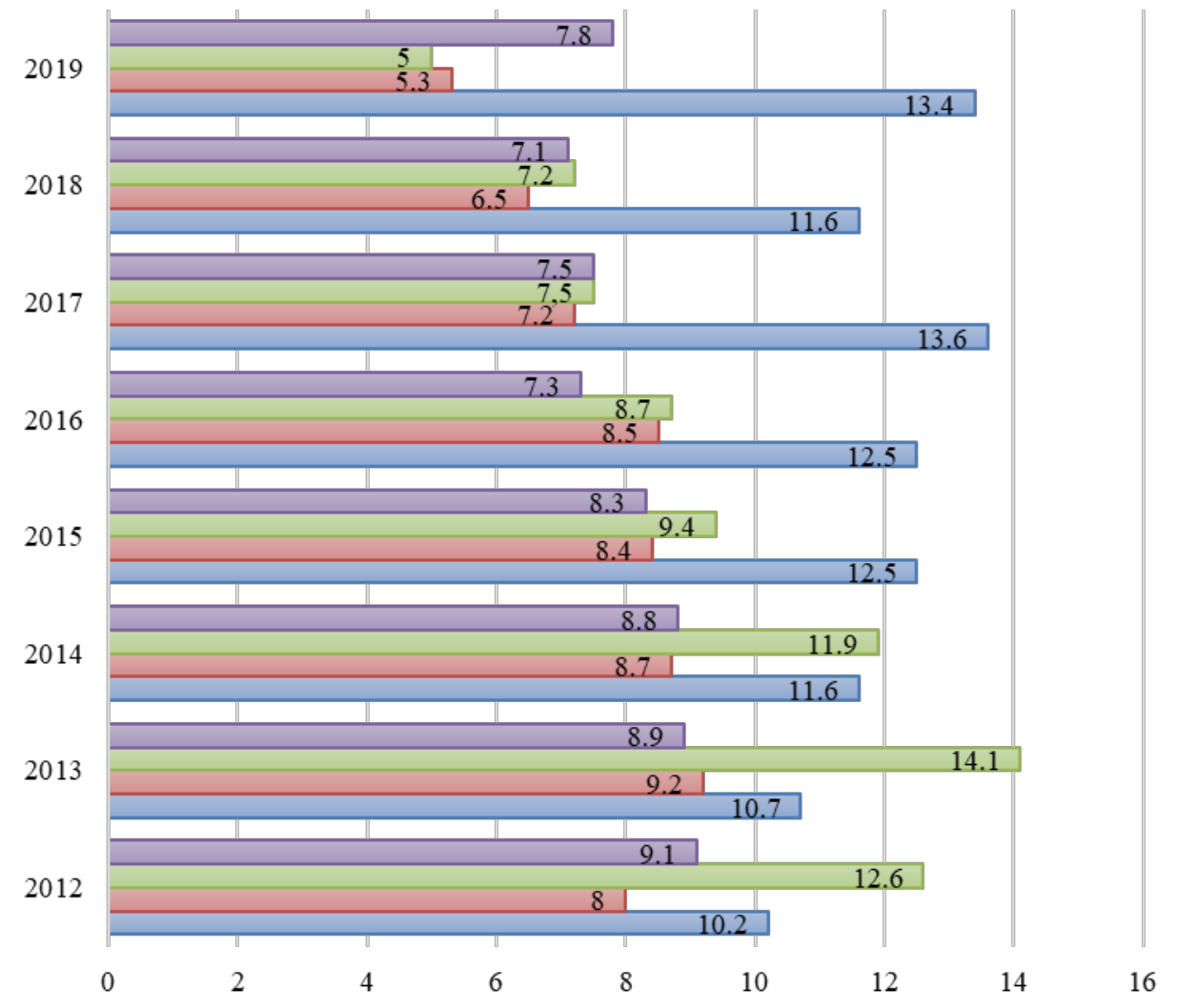

$\square$ Share of organizations engaged in technological innovation in the total number of studied organizations, \%

$\square$ Share of innovative goods, works, services in the total export of goods, works, services, \%

$\square$ Share of innovative goods, works, services in the total volume of shipped goods, performed works and services, $\%$

$\square$ Share of fundamentally new technologies in the total number of developed advanced production technol ogies, $\%$

Fig. 3. R\&D and innovation performance in 2012-2019 [10]. 
The share of organizations engaged in technological innovations decreased from $9.1 \%$ in 2012 to $7.8 \%$ in 2019 . The share of shipped innovative goods and provided services decreased over this period from $8 \%$ to $5.3 \%$, and this share dropped to $5 \%$ in total exports. A positive trend is observed in the increase in the share of fundamentally new technologies from $10.2 \%$ to $13.4 \%$ [10].

The development of the information and communication infrastructure and the availability of various types of telecommunications have a significant impact on the possibility of accelerated introduction of digital technologies (Table 1).

Table 1. Internet accessibility, 2012-2019 [10].

\begin{tabular}{|c|c|c|c|c|c|c|c|c|c|c|}
\hline No. & Indicators & 2012 & 2013 & 2014 & 2015 & 2016 & 2017 & 2018 & 2019 & $\begin{array}{r}2019 \text { to } \\
2012, \%\end{array}$ \\
\hline 1 & $\begin{array}{l}\text { Fixed broadband } \\
\text { Internet } \\
\text { subscribers per } \\
100 \text { people }\end{array}$ & 14.4 & 16.5 & 17.0 & 18.3 & 18.6 & 21.0 & 21.7 & 22.2 & 154.2 \\
\hline 2 & $\begin{array}{l}\text { Mobile } \\
\text { broadband } \\
\text { Internet } \\
\text { subscribers per } \\
100 \text { people }\end{array}$ & 63.6 & 59.8 & 64.5 & 68.1 & 71.1 & 79.9 & 86.2 & 96.4 & 151.6 \\
\hline
\end{tabular}

The number of fixed and mobile broadband Internet subscribers per 100 people during the analyzed period increased by $54.2 \%$ and $51.6 \%$, respectively.

The level of digitalization of the local telephone network in urban and rural areas increased to 95 and $87.4 \%$ in 2019 (Fig. 4).

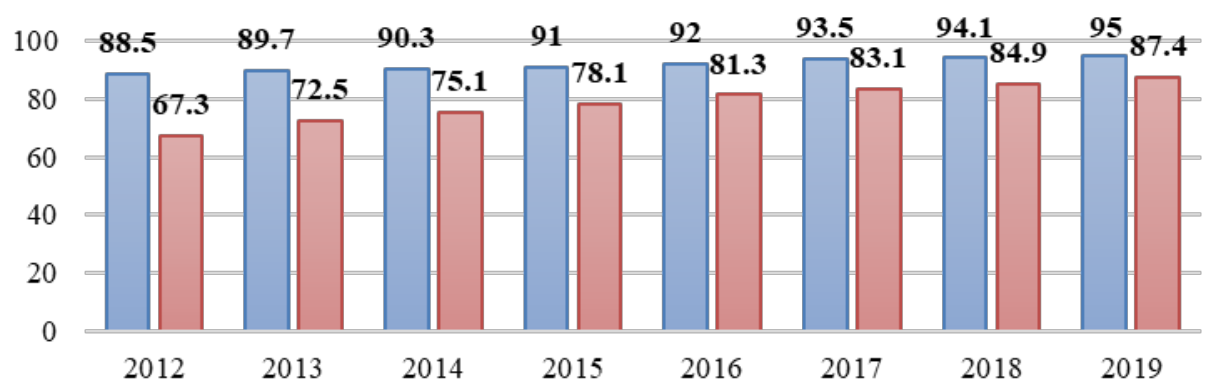

$\square$ The level of digitalization of the local telephone network in urban areas, \%

$\square$ The level of digitalization of the local telephone network in rural areas, \%

Fig. 4. The level of digitalization of the local telephone network in 2012-2019, \% [10].

The share of households with a personal computer in the total number of households increased from $66.5 \%$ in 2012 to $69.4 \%$ in 2019 , and the share of Internet users among household members increased from $54.4 \%$ to $65.4 \%$ over this period [10].

The availability of ICT use is also characterized by the availability of personal computers and mobile phones among the population. It should be noted that the number of personal computers increased by $44.19 \%$ from 2012 to 2019 , while the number of mobile phones remained almost at the same level (Table 2). 
Table 2. Availability of personal computers and mobile phones per 100 households in 2012-2019, units [10].

\begin{tabular}{|c|l|l|l|l|l|l|l|l|l|l|}
\hline No. & Indicators & $\mathbf{2 0 1 2}$ & $\mathbf{2 0 1 3}$ & $\mathbf{2 0 1 4}$ & $\mathbf{2 0 1 5}$ & $\mathbf{2 0 1 6}$ & $\mathbf{2 0 1 7}$ & $\mathbf{2 0 1 8}$ & $\mathbf{2 0 1 9}$ & $\begin{array}{c}\mathbf{2 0 1 9} \text { to } \\
\mathbf{2 0 1 2} \%\end{array}$ \\
\hline & $\begin{array}{l}\text { Number of } \\
\text { personal } \\
\text { computers } \\
\text { per 100 } \\
\text { households, } \\
\text { units }\end{array}$ & 86 & 100 & 113 & 125 & 127 & 124 & 125 & 125 & 145.3 \\
2 & $\begin{array}{l}\text { Number of } \\
\text { mobile } \\
\text { phones per } \\
\text { 100 } \\
\text { households, } \\
\text { units }\end{array}$ & 244 & 250 & 257 & 256 & 245 & 245 & 247 & 250 & 102.4 \\
\hline
\end{tabular}

In 2019, the number of Internet users among Russians over 16 years old increased to 94.4 million people or $79.8 \%$ of the adult population of the country.

The share of the population using the Internet to receive state and municipal services is growing. It increased 5 times in $2013-2019$, from $10.7 \%$ to $53.5 \%$. In the total population who received state and municipal services, this share increased to $77.6 \%$ [10]. The share of the population ordering goods and services using the Internet increased from 15.3\% in 2013 to $35.7 \%$ in 2019 (Fig. 5)

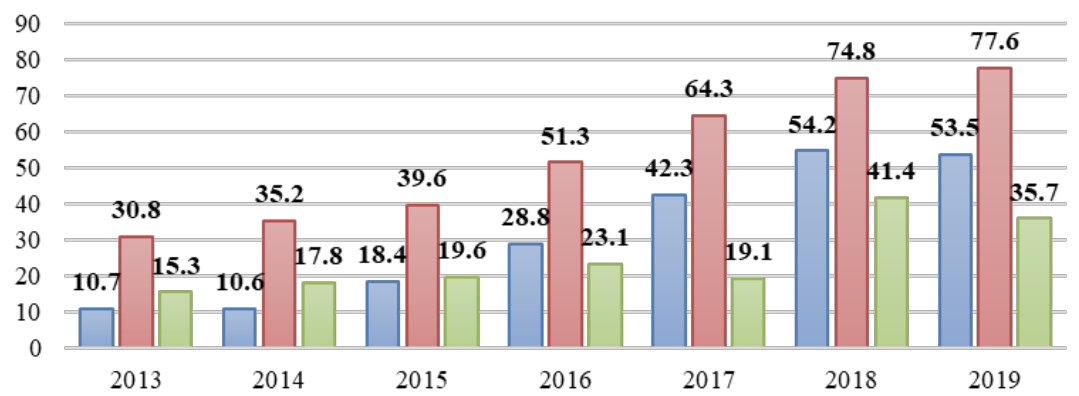

$\square$ Share of the population using the Internet to receive state and municipal services in the total number of the studied population, $\%$

$\square$ Share of the population using the Internet to receive state and municipal services in the total number of the population received state and municipal services, $\%$

$\square$ Share of the population ordering goods and (or) services using the Internet in the total number of the population, $\%$

Fig. 5. Share of population using the Internet to receive services in $2013-2019, \%$ [10].

Thus, it can be concluded that the opportunities for households and the population to use digital technologies have increased during the analyzed period.

\section{Results}

Nowadays, the spread of digital technologies has a significant impact on the development of the national economy. In most cases, their use contributes to the emergence and development of new effective management technologies, entrepreneurial practices, and successful businesses. In addition, traditional ways of conducting economic activity are 
being transformed and optimized, saturating it with information flows and inevitable acceleration against the background of both process and structural changes taking place [11, $12]$.

The reorientation of all industries, markets, areas of activity in the coming decades is predetermined by the requirements of new digital economic models. The future development of the economy is driven by the use of big data technologies, machine learning, distributed ledgers, robotization, smart things, virtual and augmented reality, wireless communications and many others, including those that visionaries are still talking about, based on unconditional and large-scale application of digital data sets $[3,15]$.

In modern conditions, the spread of digital technologies cannot be stopped, since the scale of their use is determined by the value for the consumer, the profitability for the business, and the significance for the regulator. Moreover, as the value of digital solutions grows, the cost of obtaining them decreases.

The priority task for business entities is to solve the problem of how quickly it will be possible to understand digital transformation, to learn how to safely obtain the required result.

Nowadays, the drivers of digital transformation are new products and services, new information and management technologies, innovative business models, and industry digital platforms are the key driver [11].

Besides, for the development of digital technologies, the Russian economy has a powerful reserve within the framework of government programs and other regulatory documents that provide businesses with incentives for innovation in the economic and social spheres, which is one of the key factors in the country's development [8].

In order to introduce digital technologies that are not regulated by current legislation, the Ministry of Economic Development of Russia is currently developing a new legal regime called "regulatory sandboxes". A regulatory sandbox is a test environment that needs to be set up to pilot new technologies and assess their benefits to business models and the risks they can bring. Since the current legislation does not always and fully take into account the peculiarities of the use of digital technologies, this regime is necessary for their accelerated implementation [5].

"Regulatory sandboxes" are supposed to be created on the basis of big data, blockchain, neurotechnology and artificial intelligence, quantum technologies, robotics, wireless communications, virtual and augmented reality. The introduction of this regime will provide a decrease in legal uncertainty, an acceleration of the introduction of new solutions to the market, a quick elimination of unworkable models and a reduction in costs.

The Skolkovo Foundation and the Center for Strategic Research participated in the development of the draft law on "regulatory sandboxes". Assessment of the efficiency of "regulatory sandboxes" can be carried out both on the basis of specific quantitative indicators and by comparing the achieved results with the achievements outside the "sandbox" and international experience [9].

In April 2018, a similar platform was launched by the Central Bank of the Russian Federation (CB RF) with the aim of pilot and rapid implementation of new financial services and technologies that required changes in the regulatory framework. The pilot assessment of services and technologies is being implemented by the Central Bank of the Russian Federation in cooperation with interested government agencies, specialized associations and development institutions. One of the first products tested in the sandbox was the Sberbank service. Services for organizing investment attraction in the form of token placement (ICO) have also been successfully piloted.

The digital sandbox mechanism is widespread in the IT industry for testing solutions, namely, when used to work with computer viruses, providing the ability to run applications in a protected shell, otherwise called a "sandbox". Antivirus software uses sandboxing in its 
products as a means of proactive protection of users from as yet unknown threats. For example, Kaspersky Lab used the Safe Environment technology in its products, which allows suspicious applications to be launched in the "sandbox". Google uses sandboxing in its proprietary browser - Google Chrome, placing new sites not at the beginning of the search query, in case the site turns out to be fake.

The main task of the draft Federal Law "On Experimental Legal Regimes in the Sphere of Digital Innovations" is the legalization of the functioning of innovative projects in the newest spheres of activity, which has not found its normative regulation in the current legislation. It is assumed that "regulatory sandboxes" will provide special legal regimes, within which projects in the field of the latest technological developments will be tested [9].

Due to the lack of adequate legislative regulation in Russia, it is impossible to successfully launch high-tech startups and regularly attract new investments into the economy, thereby hampering the development of the entire innovation sector. Thus, in order to create "regulatory sandboxes", it is necessary to understand new technologies, their real usefulness and applicability.

The draft law on "regulatory sandboxes" is a positive development, indicating the state's interest in dialogue with business, which in modern conditions is focused on innovation and new technologies.

At the same time, the draft law also has drawbacks associated with a cumbersome multi-level procedure. The interaction of three executive authorities at the same time (authorized, regulatory and coordinating ones) will significantly complicate all processes [9].

After further elaboration of the law, it is likely that it will be able to significantly expand the possibilities for the implementation of technological projects, including those not related to the financial sector, as well as make more attractive venture and direct investments in Russian innovations.

Experimental legal regimes will make it possible to test how a new technological solution works in practice, and to determine whether its widespread use is acceptable and what requirements should be established during its implementation [4].

The proposed "regulatory sandboxes" will help to level the legal uncertainty and bring new products to the market faster. Participants of such "sandboxes" for IT companies should be: legal entities, individual entrepreneurs, executive authorities and local governments. A company that decides to test a new technology can create its own "sandbox" or join an existing one $[5,16]$.

It should be noted that debtors of taxes and obligatory payments will not be able to get into the "sandboxes", and enterprises with an unexpunged or unspent conviction of a manager and/or chief accountant for economic crimes in the last five years and for other reasons will not be allowed.

The draft law provides for the creation of experimental regimes for a period not exceeding three years. If the result is successful, the authorized body (while this issue is unclear) will be able to come up with a proposal to change laws in the field of the tested technology. The draft law states that the "sandboxes" do not equalize tax implications and mandatory payments. Experimental regimes will also not have to apply to the sphere of defense and security, internal and foreign affairs.

\section{Conclusions}

Thus, at present, the national economy has all the necessary prerequisites for further acceleration of the pace of digitalization. Digital technologies will influence the development of new business models and public administration, create a synergistic effect, and lead to the overall growth of the Russian economy. However, the main obstacle in the 
development of the digital economy is the lack of coordinated actions on the part of the state, business and the scientific community.

The main purpose of the draft law on "regulatory sandboxes" proposed by the Ministry of Economic Development of Russia is the process of testing new technologies and faster implementation of innovations against the background of reducing legal risks for market participants. In modern conditions, the development of digital and innovative technologies is not effective due to the imperfection and conservatism of the legal framework of the Russian Federation, since regulatory documents do not always and fully take into account the specifics of innovations. Therefore, to test the effectiveness of new developments, it is necessary to test them in conditions close to real ones, with all the possibilities and limitations that regulation brings.

\section{References}

1. "On the strategy of scientific and technological development of the Russian Federation" (Consultant Plus) http://www.consultant.ru/document/cons_doc_LAW_207967

2. Administration of the President of the Russian Federation, http://kremlin.ru/

3. Office of the Government of the Russian Federation, http://government.ru /

4. A single portal for posting information on the development of draft normative legal acts by federal executive authorities and the results of their public discussion, http://regulation.gov.ru /

5. The Ministry of Economic Development proposed to create "sandboxes" for testing innovations, $\quad$ https://www.vedomosti.ru/technology/news/2019/01/11/791190eksperimentalnih-pravovih-rezhimov

6. Open government, http://open.gov.ru/events/5515775/

7. Passport of the national program "Digital Economy of the Russian Federation", http://www.consultant.ru/

8. A.V. Bataev, A.A. Gorovoy, A.B. Mottaeva, Proceedings of the 32nd International Business Information Management Association Conference, IBIMA 2018 - Vision 2020, 102-114 (2018)

9. Draft Federal Law "On Experimental Legal Regimes in the Field of Digital Innovation”, https://digital.gov.ru/ru/

10. A. Mottaeva, J. Stepanova, N. Meshkova, G. Semenova, European Journal of Sustainable Development 10(1), 705-723 (2021) Doi: 10.14207/ejsd.2021.v10n1p705

11. Digital Russia: New Reality (McKinsey Global Institute, 2017) http://www.tadviser.ru/images/c/c2/Digital-Russia-report.pdf

12. A. Sergeev, L. Akhmetshina, K. Grabovyy, E3S Web of Conferences 110, 02153 (2019) https://doi.org/10.1051/e3sconf/201911002153

13. N.S. Khoroshavina, A.V. Sharkova, O.N. Vasilyeva, O.V. Borisova, K.O. Sokolov, Espacios 39(41), 10 (2018) ISSN: 07981015

14. S. Rakhimova, K. Kunanbayeva, L. Goncharenko, A. Pigurin, E3S Web of Conferences 110, 02154 (2019) DOI: 10.1051 / e3sconf / 201911002154

15. E. Eliseeva, 17th International multidisciplinary scientific GEOconference SGEM 2017 (Albena, Bulgaria, 2017) DOI: 10.5593/sgem2017/53

16. E. Ganebnykh, O. Lezhnina, J. Zhukova, V. Kashintseva, E3S Web of Conferences 210, 10008 (2020) https://doi.org/10.1051/e3sconf/202021010008 